\title{
Life, Death, Hurricanes, Covid-19, and American Financial Inequality
}

\author{
Stephan A. Schwartz \\ Saybrook University
}

This paper, on the basis of objectively verifiable social outcome data, describes the increasingly grotesque financial inequality that obtains in the United States of America today. It shows how the wealth difference between rich and poor has become so great that these two demographics essentially live in different worlds, different realities. It also presents data showing that this wealth disparity has had a negative impact on the nation's democracy, and American society's ability to respond to crises like hurricanes, and pandemics. Finally, it proposes, again based on social outcome data, how non-violent social change that emphasizes wellbeing provides an optimal path to the future.

Keywords: financial inequality, democracy, crisis management, hurricanes, Covid-19, Coronavirus, social wellbeing

In October 2018, as Hurricane Michael devastated Puerto Rico, the East Coast and the panhandle of Florida, within the images those crises produced, like the bobbing head of a drowning man, I began to see a secondary story line. It was one I had first become aware of less than a month earlier when newspaper stories and cable news accounts appeared reporting how the Federal government had failed people caught up in the catastrophic flooding that accompanied Hurricane Florence. One that I read in the British Guardian newspaper, an interview with a 57-year-old man in Myrtle Beach, South Carolina particularly stood out for me. A reporter asked the man why he had stayed in his home when he could have gotten out. His answer, "It's too expensive to move out to a hotel. I could be out for days and I can't afford to leave my home behind."

As I continued to read and watch over the next months it turned out this story of poverty defining response to a catastrophe, far from being a singularity was in fact commonplace, although reporters almost never described this as a trend. I began to search out both human stories and research studies, and realized I was seeing a social trend defined by objectively verifiable data. One that now, in the midst of the Covid-19 pandemic, I think, has become a dominant trend in 21st century America: The negative effect of an economics in which profit is the only social priority.

Anyone who works with recurring systems, whether engineer, physician, or economist, knows the principle: When you stress a system its weaknesses and flaws become obvious. To me, hurricanes and Covid-19, although superficially very different, are both examples of extreme stress saying the same thing. American wealth inequality has become so great it has created two worlds. Distinct worlds whose needs, wants, and hopes have become so different they are no longer really connected. As the data shows, how you experience a hurricane or a pandemic is very different depending on whether you are rich or poor.

Dr. Stacy Willett, professor in the Department of Disaster Science and Emergency Services has identified six major reasons why people ignore mandatory evacuation notices: age, gender, previous 
experience, cost, pets and the influence of others. ${ }^{2}$ As I read her data, of those six, cost was the one that stood out. Rich or poor might choose to stay if it was about pets. Age and gender are also commonalities. But cost is not. Only the poor are affected by cost. And that made me think about the level of power financial inequality has assumed in defining our culture. It has become a social constant in our lives, although it is rarely discussed in that way.

As I write this in April 2020, we are a nation of 331 million people. The inequity of affluence in the country is staggering. Actually, I think it is grotesque. On what basis do I say this? Chuck Collins and Josh Hoxie of The Institute for Policy Studies did relevant research that makes the difference clear. Using data from both the recently released 2017 Forbes 400 and the Federal Reserve's 2016 Survey of Consumer Finances, they addressed the issue. Here are some of their key findings:

1. "The three wealthiest people in the United States - Bill Gates, Jeff Bezos, and Warren Buffett - own more wealth than the entire bottom half of the American population combined, a total of 160 million (now over 165 million) people or 63 million house-holds (now 128 million).

2. "America's top 25 billionaires together hold $\$ 1$ trillion in wealth. They have as much wealth as 56 percent of the population, a total 178 million people or 70 million households.

3. "The billionaires who make up the full Forbes 400 list own more wealth than the bottom 64 percent of the U.S. population, an estimated 80 million households or 204 million people.

4. "The median American family has a net worth of $\$ 80,000$, excluding the family car. The Forbes 400 own more wealth than 33 million of these typical American families.

5. "One in five U.S. households has zero or negative net worth. 'Underwater households' make up an even higher share of households of color. More than 30 percent of black households and 27 percent of Latino households have zero or negative net worth to fall back on."3

Scheidel, who is very conservative in interpreting his data, felt compelled to note: " $\ldots$ attempts to ease inequality democratically through redistributive policies and the empowerment of labor at least show no signs of doing actual harm.",

As I thought about those facts and the human stories of people too poor to get out of the way of a catastrophe, I saw those stories as the representation of the almost obscene inequality that prevails in America today. And now as I am watching the Covid-19 crisis play out I see that grotesque financial inequality once again brought to the fore. As Anna North wrote in Vox, “... with every day that goes by, it becomes more clear that the virus... is exacerbating the inequalities in American society, taking a disproportionate toll on low-income Americans, people of color, and others who were already marginalized before the crisis hit."

A critic might say, "Rich and poor people alike can catch the virus," and that is true but, based on data, irrelevant. Those of wealth and those in poverty do not experience crisis events of whatever kind in the same way. And when racism is also included as a factor the differences become even more glaring. In a New York Times Study, "In Illinois, 43 percent of people who have died from the disease and 28 percent of those who have tested positive are African-Americans, a group that makes up just 15 percent of the state's population. African-Americans, who account for a third of positive tests in Michigan, represent 40 percent of deaths in that state even though they make up 14 percent of the population. In Louisiana, about 70 percent of the people who have died are black, though only a third of that state's population is. ${ }^{6}$

As I watched Hurricane Michael at a distance, and now, living through Covid-19, I have begun to think about Alexis Charles Henri Clerel de Tocqueville, scion of one of the oldest Norman noble families in France, who in 1831 came to the United States accompanied by his close friend Gustave de Beaumont.

Officially he had been sent to study America's prison system. In fact, he also sought to learn what was happening in a country that had weathered revolution and had begun a social experiment whose echoes were still sweeping across Europe. Travelling throughout the States the two men spent nine months observing, reading the local press, and talking with Americans both rich and poor. Out of those experiences de Tocqueville crafted Democracy in America, one of the enduring masterpieces of cultural and political observation about democracy and inequity. ${ }^{7}$ 
Although the representative of a culture that almost worshipped continuity and class differences, de Tocqueville saw, and more importantly appreciated, that the crux of democracy was the capacity for change. He wrote that Americans ". . have all a lively faith in the perfectibility of man...; they consider society as a body in a state of improvement, humanity as a changing scene, in which nothing is, or ought to be, permanent; and they admit that what appears to them today to be good, may be superseded by something better tomorrow." He understood that America was defined in its quest for change by its desire for "an equality of condition amongst its citizens." ${ }^{\prime 8} \mathrm{He}$ described liberty as the ultimate political value and wrote that democracy was the irresistible future.

De Tocqueville's principal passion was equality, an issue perhaps even more resonant today than it was in the mid-19th Century. He saw what history has made apparent: liberty, equality and the ability to change lie at the core of social fairness. The difference is that in de Tocqueville's day equality was much more emphatically a function of resources. There was not enough to go around.

In the early years of the American story even wealthy people did not have many things, as anyone who visits George Washington's Mount Vernon, and sees the spareness of the room furnishings quickly appreciates. The challenge of equality today is not that there is not enough to go around, but that as a society America has lost its sense of fairness concerning its distribution and how we collectively feel we should treat others individually. As a result, a growing number of historians and political scientists are crying out that we are in very real danger of losing our democracy. Worse, the data is explicit: this trend is growing year by year.

We have become in substance antipodal to the American lie we tell ourselves about ourselves. Am I exaggerating? Try this on, "The United States has the highest rate of income inequality among Western countries." In 2018 Forbes reported "the United States had over 25 per cent of the world's 2,208 billionaires." ${ }^{\prime 10}$ Bloomberg reported that Jeff Bezos " ... has added almost \$24 billion to his fortune in 2020, as well as MacKenzie Bezos, who was left with a 4\% stake in Amazon as part of the couple's recent divorce settlement. Her net worth has climbed $\$ 8.2$ billion to $\$ 45.3$ billion, and she's now No. 18 on the Bloomberg wealth ranking, ahead of Mukesh Ambani, India's richest person, and Mexico's Carlos Slim." ${ }^{" 11}$ How very different a world compared to the democracy envisioned by de Tocqueville.

So pronounced has American financial inequality become that in 2018, when Phillip Alston, the United Nations Special Rapporteur on extreme poverty and human rights, was sent to the United States to assess the nation's inequality on the basis of data, not politics. He found that there was not another Western country with inequality as pronounced as that of the United States, and in 2020 this trend is getting worse.

Alston reported, "The $\$ 1.5$ trillion in tax cuts in December 2017 overwhelmingly benefited the wealthy and worsened inequality. The consequences of neglecting poverty and promoting inequality are clear. The United States has one of the highest poverty and inequality levels among the OECD countries, and the Stanford Center on Inequality and Poverty ranks it 18th out of 21 wealthy countries in terms of labour markets, poverty rates, safety nets, wealth inequality and economic mobility.... For almost five decades the overall policy response has been neglectful at best, but the policies pursued over the past year seem deliberately designed to remove basic protections from the poorest, punish those who are not in employment and make even basic health care into a privilege to be earned rather than a right of citizenship." 12

This plays out at every level including the most basic: how long a person lives. The Centers for Disease Control assembled mortality data from around the country, and as Julia Belluz of Vox, reported, "Living in the US increasingly looks like a health risk. Average life expectancy here dropped for the second year in a row, according to recent data from the Centers for Disease Control and Prevention. The grim trend stems from a toxic mixture of more drug-and alcohol-related deaths and more heart disease and obesity in many parts of the country. And it puts Americans at a higher risk of early death compared to their counterparts in other wealthy countries.... this trend isn't affecting all Americans. In fact, there's one group in the US that's actually doing better than ever: the rich. While poor and middle-class Americans are dying earlier these days, the wealthiest among us are enjoying unprecedented longevity."13 
It is generally acknowledged by those who study the issue in depth that the American middle class arose from the extensive unionization of the workforce beginning in the 1920s, and brought to fruition at the end of World War II when millions of returning service men and women became eligible for educational benefits and real estate financing thanks to programs begun by Franklin Roosevelt and continued and augmented by Harry Truman and the Democrats. Beginning in the early 1950s these efforts created the vibrant middle class that most of us think of as the norm and that made America the envy of the world

Angus Deaton, 2015 winner of the Nobel Prize in economics and Presidential Professor of Economics at the University of Southern California as well as Professor of Economics and International Affairs at Princeton University's Woodrow Wilson School of Public and International Affairs, working with Anne Case, an economist also at the Woodrow Wilson School, analysed a vast amount of U.S. data on health and death in the U.S. which they published in the Proceedings of the National Academy of Science. It was a report so devastating that some in non-US media, as well as fellow economic Nobel Laureates such as Joseph Stiglitz, considered it as important as Deaton winning the Nobel, and publicly said so. ${ }^{14}$ In the U.S. it received very little media attention and few Americans know about it.

Anne Case, to acknowledge her first author position, and Deaton reported, "a marked increase in the all-cause mortality of middle-aged white non-Hispanic men and women in the United States between 1999 and 2013. This change reversed decades of progress in mortality and was unique to the United States; no other rich country saw a similar turnaround."15

But that's only part of it, "The midlife mortality reversal was confined to white non-Hispanics; black non-Hispanics and Hispanics at midlife, and those aged 65 and above in every racial and ethnic group, continued to see mortality rates fall.",16

They also looked at why this anomaly was occurring, and reported, "This increase for whites was largely accounted for by increasing death rates from drug and alcohol poisonings, suicide, and chronic liver diseases and cirrhosis. Although all education groups saw increases in mortality from suicide and poisonings, and an overall increase in external cause mortality, those with less education saw the most marked increases. Rising midlife mortality rates of white non-Hispanics were paralleled by increases in midlife morbidity. Self-reported declines in health, mental health, and ability to conduct activities of daily living, and increases in chronic pain and inability to work, as well as clinically measured deteriorations in liver function, all point to growing distress in this population." ${ }^{.17}$

How solid is their data? They analyzed "all-cause mortality of men and women in the United States between 1999 and 2013." All of them. Joseph Stiglitz in his commentary on the report said, "The CaseDeaton results show that such theories will no longer do. America is becoming a more divided society divided not only between whites and African Americans, but also between the $1 \%$ and the rest, and between the highly educated and the less educated, regardless of race. And the gap can now be measured not just in wages, but also in early deaths. White Americans, too, are dying earlier as their incomes decline." $" 18$

Case and Deaton even discuss one of the major changes in retirement policies in the U.S. as being a significant cause of this growing inequality. "The United States has moved primarily to definedcontribution pension plans with associated stock market risk, whereas, in Europe, defined-benefit pensions are still the norm."19

I have written elsewhere about the Theorem of Wellbeing, ${ }^{20}$ the idea that policies which foster wellbeing are always healthier, more efficient, easier to implement, nicer to live under, longer enduring and much, much, cheaper. Conversely, policies that have other priorities will be less-healthy, less efficient, harder to implement, less pleasant to live under, of shorter duration, and more expensive, usually much more expensive. This one change concerning retirement, engineered by corporate lobbyists and the Congress members they had purchased through political contributions, is a negative proof of the Theorem and a leading cause of the inequality that is eating away at American democracy.

Peter Drucker is a hard man to characterize, but most economists and management authorities would concur that he was one of the most powerful influences in shaping the philosophy and management of modern corporations in the 20th century. The Drucker Institute and the Peter F. Drucker and Masatoshi 
Ito Graduate School of Management, both at Claremont Graduate University, as well as the Peter F. Drucker Academy, attest to his stature. As does the annual Global Peter Drucker Forum in his hometown of Vienna, Austria.

Drucker, who studied this inequality issue over many years, “... advocated a ratio around 25 to 1 (as he suggested in a 1977 article) or 20 to 1 (as he expressed in a 1984 essay and several times thereafter). "Widen the pay gap much beyond that," he said, "and it makes it difficult to foster the kind of teamwork and trust that businesses need to succeed." So generally acknowledged is this ratio that it has come to be known as the "Drucker Principle."

He said, "I have often advised managers that a 20 to 1 salary ratio is the limit beyond which they cannot go. ${ }^{21} \mathrm{He}$ elaborated on that several years later, saying in a 2004 interview, "I'm not talking about the bitter feelings of the people on the plant floor. . It's the midlevel management that is incredibly disillusioned by king size CEO compensation." 22

So, what is the actual CEO to worker ratio in the United States today? At the time of Hurricane Michael in 2018, Michael Norton, a professor at the Harvard Business School, and Sorapop Kiatpongsan of the the Chulalongkorn University in Bangkok, Thailand, closely examined that very question. They surveyed about 55,000 people all over the world. Included were 1,581 U.S. participants. They found, "In the 1960s, the typical corporate chieftain in the U.S. earned 20 times as much as the average employee. Today, depending on whose estimate you choose, he makes anywhere from 272 to 354 times as much. According to the AFL-CIO, the average CEO takes home more than $\$ 12$ million, while the average worker makes about $\$ 34,000$."23

A year later, in 2019, a study by Lawrence Mishel and Julia Wolfe of the Economic Policy Institute confirmed all this, and added: "From 1978 to 2018, CEO compensation grew by 1,007.5\% (940.3\% under the options-realized measure), far outstripping S\&P stock market growth $(706.7 \%)$ and the wage growth of very high earners (339.2\%). In contrast, wages for the typical worker grew by just $11.9 \%$."24

Research done by the Schwartz Center for Economic Policy Analysis (no connection with author) found, "Roughly 40 percent of Americans who are considered middle class (based on their income levels) will fall into poverty or near poverty by the time they reach age 65 ," as a result of "depressed earnings, depressed asset values, and increased health-care costs. ${ }^{\prime 25}$ Seventy four percent of Americans will have to work past traditional retirement age. ${ }^{26}$

And it goes without saying that financial inequality has a very significant racial and gender aspect, and it is much worse than most Americans, even most researchers, realize. The Save the Children Foundation commissioned a study on this topic, and Lisa Wise, one of the report's authors, when interviewed about her study's conclusions, said the researchers were surprised. "It's one of those cases where it (the United States) should be performing better," she said, noting that it showed gender equality isn't unique to developing countries. "Girls in relation to boys are denied their opportunities in highincome countries too."27 Just how bad is it? "The US, the world's biggest economy, ranks below Kazakhstan and Algeria for gender equality, according to a report showing the countries that offer the most opportunities for girls. The US came 32nd in the index due to its low representation of women in parliament, high teenage pregnancy rates, and its record on maternal deaths. According to the Centers for Disease Control if you limit your list to the developed countries the U.S. comes in last. If one includes all the nations of the world we come in 55 th. $^{28}$

In racial terms wealth inequality, always bad in the U.S., is getting worse. In 2010, Pew Research Center, using the Federal Reserve's Survey of Consumer Finances, analyzed racial differences and found that the racial wealth difference between Whites and others that year was eight times. That is, White households had 8 times as much wealth as Black households. ${ }^{29}$ In 2013 the difference was 13 times. ${ }^{30}$ Similarly, with Hispanics, the difference was nine times in 2010, and in 2013 it had risen to over ten times.

We are headed into dangerous waters that hold profound implications for our future. To be clear, there is nothing new about inequity. Anyone who studies history recognizes the constancy of financial inequality. Walter Scheidel, at Stanford University, went all the way back to the stone age in researching this issue. He found, "that inequality within countries is almost always either high or rising, thanks to the 
ways that political and economic power buttress each other and both pass down generations. It does not, as some have suggested, carry within it the seeds of its own demise." ${ }^{31}$ And everyone who studies these things knows that when social inequality reaches a certain extreme, civil violence follows. It's different for different cultures, but the principle is always the same. And we are now facing it.

So, what should we do? I don't think the answer, in principle, is as complicated as many make it. If one looks all over the developed world it is clear that social values produce predictable social outcomes, and that just as the Theorem of Wellbeing states: those choices that are the most compassionate, lifeaffirming and fostering of wellbeing produce the most the most desirable outcomes if wellbeing from the individual, to the family, the community, the state, the nation, and the planet itself. It is not hard to pick the right option if wellbeing is the criterion for making the choice.

Most arguments about change start from the top down. But that is not how I read history. Long lasting non-violent change begins from the bottom up because it involves a change in consciousness at the social level.

The key in this change process is the individual, and it starts with what I have called the Quotidian Choice as I described it in my book on social transformation, The 8 Laws of Change:

"The secret that lies at the heart of nonviolent social transformation based on beingness is the Quotidian Choice. It is exercised very simply. Usually, it is a small moment of decision in which, of the options available, one is the most compassionate and life affirming. And you choose that one." 32

We are presented with such choices many times each day. The car we choose to drive, whether we use Round Up on our lawns. The kind of detergents we buy. The list goes on and on. When a critical mass of individuals makes the same choices concurrently, social change occurs. It can be something as small as the speed at which Gay became the more inclusive LGBT, a shift of term representing a shift in consciousness. The answer to the financial inequality is a collective change in consciousness acted upon by collective intention expressed by our votes, and the things we buy, watch, or in which we participate.

There is great urgency to this. "The world's leading climate scientists have warned. We have a dozen years to change our culture and keep the maximum of $2.7^{\circ} \mathrm{F} / 1.5^{\circ} \mathrm{C}$. If we don't achieve that every half a degree of temperature rise will significantly worsen the risks of drought, floods, extreme heat and poverty for hundreds of millions of people." ${ }^{\prime 33}$ We have very little time, and as both Hurricanes and Covid-19 have shown us, we are woefully unprepared as matters stand now.

\section{ENDNOTES}

1. Laughland O. 'I can't afford to leave my home': evacuating too costly for some in path of Hurricane Florence. The Guardian. Fri 14 Sep 2018 08.34 EDT. https://www.theguardian.com/world/2018/sep/14/myrtle-beach-poorest-evacuating-costly-hurricaneflorence. Accessed: 10 October 2018.

2. Why some people won't evacuate: FEMA Research. Phys.org. October 11, 2018 https://phys.org/news/2018-10-people-wont-evacuate-fema.html\#jCp

3. Collins $\mathrm{C}$ and Hoxie J. Billionaire Bonanza. Institute for Policy Studies. https://ips-dc.org/wpcontent/uploads/2017/11/BILLIONAIRE-BONANZA-2017-FinalV.pdf. Accessed: 10October 2018.

4. Ibid.

5. North A. Every aspect of the coronavirus pandemic exposes America's devastating inequalities. https://www.vox.com/2020/4/10/21207520/coronavirus-deaths-economy-layoffs-inequality-covidpandemic. Accessed: 10 April 2020

6. Eligon J, Burch A, Searcey D, Oppel R. Black Americans Face Alarming Rates of Coronavirus Infection in Some States. The New York Times 7 April 2020. Accessed: 7 April 2020. https://www.nytimes.com/2020/04/07/us/coronavirus-race.html

7. De Tocqueville. A. Democracy in America. The Henry Reeve Text as Revised by Francis Bowen and edited by Phillips Bradley. Vintage Classics: New York, 1990

8. Ibid

9. World Income Inequality Database, available at www.wider.unu.edu/project/wiid-world-incomeinequalitydatabase. Accessed: 17 April 2020.

10. See 
www.forbes.com/sites/forbespr/2018/03/06/forbes-32nd-annual-worlds-billionairesissue/\#43e9e95a10e0. Accessed: 10 October 2018

11. Alexander S, Maloney T, and Metcalf T. Jeff Bezos Gains $\$ 24$ Billion While World's Rich Reap Bailout Rewards. Bloomberg. https://sg.finance.yahoo.com/news/jeff-bezos-gains-us-24-billion-while-worlds-richreap-bailout-rewards-025222177.html. Accessed: 17 April 2020

12. Alston P. Report of the Special Rapporteur on extreme poverty and human rights on his mission to the United States of America. Human Rights Council, United Nations. 18 June-6 July 2018. A/HRC/38/33/Add.1. Accessed: 10 October 2018.

13. Belluz. J. What the dip in US life expectancy is really about: inequality. Vox. Jan 9, 2018, 9:50am EST. https://www.vox.com/science-and-health/2018/1/9/16860994/life-expectancy-us-income-inequality. Accessed: 10 October 2018.

14. Stiglitz J. Inequality is now killing middle America. The Guardian. Tuesday 8 December 201504.04 EST. http://www.theguardian.com/business/2015/dec/08/inequality-is-now-killing-middle-america-josephstiglitz. Accessed: 8 December 2015.

15. Case A and Deaton A. Rising morbidity and mortality in midlife among white non-Hispanic Americans in the 21st century. PNAS. September 17, 2015. http://www.pnas.org/lookup/suppl/doi:10. 1073/pnas.1518393112/-/DCSupplemental. Accessed: 8 December 2015.

16. Ibid

17. Ibid

18. Stiglitz Op Cit.

19. Ibid

20. Schwartz S. The Wellness Theorem: A Test of Hypothesis. Explore. Vol. 12, Issue 5, pp. 310-313. https://www.explorejournal.com/article/S1550-8307(16)30077-5/fulltext.

21. Hunter J. Peter Drucker Advocated a Ratio of 20 to 1 for CEO to Average Worker Pay. February 9, 2015. The W. Edwards Deming Institute. https://blog.deming.org/2015/02/peter-drucker-advocated-a-ratio-of-20to-1-for-ceo-to-average-worker-pay/. Accessed: 17 April 2020.

22. Ibid.

23. Weissmann J. Americans Have No Idea How Bad Inequality Really Is. Slate. Sept. 262014 12:49 PM. http://www.slate.com/articles/business/moneybox/2014/09/americans_have_no_idea_how_bad_inequality_ is_new_harvard_business_school.html. Accessed: 12 October 2018

24. Mishel $\bar{L}$ and $\bar{W}$ olfe J. CEO compensation has grown $940 \%$ since 1978 . Economic Policy Institute. 14 August 2019. https://www.epi.org/publication/ceo-compensation-2018/ Accessed: 17 April 2020.

25. Dinkin E. $40 \%$ of the American middle class face poverty in retirement, study concludes. CNBC 12 October 2018. https://www.cnbc.com/2018/10/12/40percent-of-american-middle-class-face-poverty-inretirement-study-says.html. Accessed: 12 April 2020.

26. Ibid

27. MacSwan A. US ranks lower than Kazakhstan and Algeria on gender equality. The Guardian. Tuesday 11 October 2016 | 17.00 EDT. Accessed: 16 April 2020.

28. Hoyert D and Minino A. Maternal Mortality in the United States: Changes in Coding, Publication, and Data Release, 2018. National Vital Statistics Reports. Vol. 60. No. 2. 30 January 2020. https://www.cdc.gov/nchs/data/nvsr/nvsr69/nvsr69_02-508.pdf. Accessed: 18 April 2020.

29. Kochhar R and Fry R. Wealth inequality has widened along racial, ethnic lines since end of Great Recession. Pew Research Center. December 12, 2014. http://www.pewresearch.org/facttank/2014/12/12/racial-wealth-gaps-great-recession/. Accessed: 12 April 2020.

30. Ibid.

31. Scheidel W. The lessons of violence and inequality through the ages. The Economist. 2 March 2017. https://www.economist.com/news/books-and-arts/21717801-only-catastrophe-truly-reduces-inequalityaccording-historical-survey-lessons. Accessed: 2 March 2017.

32. Schwartz S. The 8 Laws of Change. Park Street Press: Rochester, Vt, 2016.

33. Watts J. We have 12 years to limit climate change catastrophe, warns UN. Mon 8 Oct 201802.23 EDT. https://www.theguardian.com/environment/2018/oct/08/global-warming-must-not-exceed-15c-warnslandmark-un-report. Accessed: 18 April 2020 